\title{
UPORABA MATERINSKOGA JEZIKA U RAZREDNOM DISKURSU NA SATU ŠPANJOLSKOGA JEZIKA
}

\author{
Andrea-Beata Jelić \\ Filozofski fakultet Sveučilišta u Zagrebu \\ Nikolina Vlašićc* \\ Turistička i ugostiteljska škola u Dubrovniku
}

\begin{abstract}
Uporaba materinskoga jezika u nastavi stranih jezika tema je koja već više desetljeća izaziva prijepore znanstvenika i stručnjaka u području glotodidaktike. Suvremeni pogled na ovu problematiku uključuje prepoznavanje važnosti uloge materinskoga jezika u procesu ovladavanja inim jezikom. Ipak, kad se ono odvija u formalnoj sredini, postavlja se niz pitanja o značajkama uporabe materinskoga jezika. Cilj ovoga rada bio je utvrditi učestalost i funkcije uporabe hrvatskoga jezika na satu španjolskoga kao stranoga jezika te ispitati stavove učenika i nastavnika u vezi s tim pitanjem. Prikupljeni podaci ukazuju na to da se hrvatski jezik u nastavi španjolskoga jezika upotrebljava više od polovice vremena za niz funkcija među kojima su najzastupljenije uklanjanje nejasnoća, usporedba materinskoga i stranoga jezika, organizacija rada i održavanje discipline te objašnjavanje gramatičkoga sadržaja. Učenici i nastavnici imaju pozitivan stav o ulozi materinskoga jezika u procesu ovladavanja inim jezikom u formalnoj sredini i većinom se zalažu za njegovu uporabu na satu španjolskoga jezika u onim funkcijama u kojima se on i rabi. Naglašava se, međutim, da uporaba J1 u velikoj mjeri ovisi o situaciji i o okolnostima u kojima se poučavanje odvija.
\end{abstract}

Ključne riječi: uporaba materinskoga jezika, hrvatski kao materinski jezik, španjolski kao strani jezik (ELE), komunikacija na satu stranoga jezika.

\section{UVOD: MATERINSKI JEZIK U PROCESU OVLADAVANJA INIM JEZIKOM U FORMALNOJ SREDINI}

Tema uloge materinskoga jezika (J1) u procesu ovladavanja inim jezikom već je više desetljeća zanimljiva istraživačima i praktičarima. Njihovi stavovi kretali su se na kontinuumu od isključive uporabe materinskoga jezika do zabrane njegova korištenja. Pobornici suvremenih pristupa svjesni su važnosti uloge materinskoga jezika u procesu ovladavanja inim jezikom, pa tako ne samo da prihvaćaju njegovu uporabu nego se za nju i zalažu (Brown, 2000; Cook, 2001; Galindo Merino, 2011; Levine, 2012; Nation, 2003; Schweers, 1999). Kad je riječ o formalnom poučavanju stranoga jezika (SJ) koje se odvija u okruženju u kojem nastavnik dijeli J1 s učenicima gotovo

\footnotetext{
abjelic@ffzg.hr

** nikolina.vlasic1@gmail.com
} 
je nemoguće, pa i nepotrebno, u potpunosti odvratiti nastavnike i učenike od korištenja J1 (Dujmović, 2007; Nation, 2003) iako je „vrlo teško odrediti koliko, kako i kada učinkovito rabiti prvi jezik kao dragocjeno sredstvo u pomoći u procesu poučavanja inoga jezika, osobito s obzirom na različitosti uvjeta u kojima se poučavanje događa“" (Erk, 2018: 275).

Dobro je poznato da se komunikacija u učionici znatno razlikuje od one u prirodnom okruženju, u prvom redu zbog činjenice da je komunikacijsko okruženje u njoj umjetno stvoreno te ono obiluje simuliranim situacijama koje služe uvježbavanju pojedinih sastavnica jezičnoga koda (Čurković Kalebić, 2008; Vrhovac, 2001, 2003). Mnogi autori (Brown, 2000; Čurković Kalebić, 2002, 2008; Ellis, 2009; Gass, 2003; Thoms, 2012; Vrhovac, 2001) navode da je razredni diskurs vrlo često pod kontrolom nastavnika te su dijalozi, tradicionalno, vrlo često u obliku: nastavnikovo pitanje - učenikov odgovor - nastavnikova reakcija (prihvaćanje, vrednovanje ili komentar). Obično govorimo o dva tipa komunikacije u razredu (Čurković Kalebić, 2002, 2003; Ellis, 2009; Vrhovac, 2003, 2005): (a) pseudokomunikacija, koja se temelji na unaprijed poznatim sadržajima iz udžbenika i služi za provjeru naučenoga, zbog čega izrečeno nema pravu komunikacijsku vrijednost; prenosi se nova informacija, ali na način na koji se $u$ prirodnom govoru vjerojatno ne bi prenijela i (b) prava komunikacija, koja omogućuje stvarnu razmjenu informacija u situacijama u kojima bi se učenici mogli naći izvan didaktičkoga okruženja pa u ovom slučaju nije riječ tek o reprodukciji nastavnoga sadržaja. Često je, također, na nastavnom satu tijekom interakcije tema sam jezik pa možemo govoriti i o metajezičnoj funkciji govora, a ona podrazumijeva govor o jezičnom sustavu i njegovim zakonitostima kao i o, primjerice, sličnostima i razlikama sa sustavom J1. Govoreći o razrednoj interakciji, razni autori (Galindo Merino, 2012; Macaro, 2005, 2009) spominju pojam prebacivanja koda (engl. code-switching; šp. alternancia/cambio de código) gdje J1 ima ulogu temeljnog jezika koji djeluje poput okvira za proizvodnju na inom jeziku, a Carlsson (2010) u tom kontekstu kao neke od razloga prebacivanja koda navodi lingvističku nesigurnost, promjenu teme, nemogućnost pronalaska ekvivalenta na stranom jeziku i spontane reakcije.

Različite su funkcije J1 uočene u procesu poučavanja ciljnoga jezika u formalnom okruženju. Sažimajući radove koji su se bavili tim pitanjem, Kerr (2019) govori o dva područja uporabe J1: temeljne funkcije (engl. core functions) povezane su s poučavanjem jezika i uključuju objašnjavanje gramatičkoga i leksičkoga sadržaja te provjeru razumijevanja tog sadržaja kao i tekstova, dok se društvene funkcije (engl. social functions) odnose na upravljanje razrednim okruženjem u smislu organizacije odnosa među sudionicima razrednog diskursa, davanja uputa ili rješavanja administrativnih pitanja. Galindo Merino (2012) spominje i funkcije koje uključuju usporedbu struktura J1 i ciljnoga jezika, obradu sociokulturnih sadržaja, davanje 
povratnih informacija, ispravljanje pogrešaka, vrednovanje te poticanje učenika na uporabu ciljnoga jezika. Navedene funkcije mogu unaprijediti proces ovladavanja inim jezikom $\mathrm{u}$ formalnoj sredini, a zastupljenost njihove uporabe ovisi o različitim jezičnim i nejezičnim čimbenicima vezanim uz okruženje u kojem se poučavanje odvija.

$\mathrm{O}$ temi uloge $\mathrm{J} 1 \mathrm{u}$ procesu ovladavanja inim jezikom $\mathrm{u}$ formalnoj sredini provedena su mnoga istraživanja, a prema Erk (2017) prevladavaju tri područja interesa: povezanost uporabe J1 u nastavi i leksičkoga i gramatičkoga znanja učenika, uporabe strategija i razvoja metaforičke kompetencije, zatim učestalost uporabe J1 u nastavi stranoga jezika i funkcija koje on može imati iz perspektive nastavnika i iz perspektive učenika i, konačno, stavovi nastavnika i učenika o uporabi materinskoga jezika u procesu učenja i poučavanja. Za naš rad posebno su zanimljiva istraživanja o učestalosti i funkcijama uporabe $\mathrm{J1}$ te ona o stavovima nastavnika i učenika (Carlson, 2010; Forteza Fernández, 2015; Galali, i Cinkara, 2017; Levine, 2003, 2012; Moghadam i dr., 2014; Turnbull i Dailey O'Cain, 2009) iako je njihove zaključke kao i eventualne preporuke za nastavnu praksu vrlo teško generalizirati s obzirom na raznolikost konteksta u kojima su se ona odvijala. Između ostalih, Schweers (1999) se u svom istraživanju u hispanofonom kontekstu bavio učestalošću i funkcijama uporabe španjolskoga kao J1 u nastavi engleskoga kao stranoga jezika te stavovima studenata i nastavnika. Podaci o učestalosti uporabe prikupljeni su snimanjem nastavnih sati, a o funkciji i stavovima upitnikom. Rezultati ukazuju na velike razlike $u$ učestalosti uporabe J1 kod pojedinih nastavnika, a većina učenika $(88,7 \%)$ i svi nastavnici zalažu se za uporabu J1 u nastavi u koju su uključeni. Obje skupine ispitanika u prvom redu ističu potrebu uporabe J1 u objašnjavanju složenijih pojmova, objašnjavanju novog vokabulara i provjeri razumijevanja. Galindo Merino (2012) je u sklopu opsežnijeg istraživanja o prebacivanju koda u različitim kontekstima ovladavanja španjolskim jezikom provela istraživanje s učenicima rane odrasle dobi koji svi dijele engleski kao J1. Cilj je istraživanja, između ostaloga, bio utvrditi učestalost i funkcije uporabe J1 kao i stavove učenika i nastavnika. Podaci su prikupljeni promatranjem nastavnih sati, upitnikom za učenike i polustrukturiranim intervjuom za nastavnike. Analiza promatranih sati nastave ukazuje da je zastupljenost J1 55 \%, a J1 najčešće se koristi za objašnjavanje, ispravljanje te davanje uputa i zadaća. Nastavnici i učenici smatraju da u formalnom kontekstu ovladavanja J1 svakako ima svoju ulogu, a potrebnu razinu zastupljenosti u nastavi povezuju s razinom znanja učenika.

Ovo pitanje istraživalo se i u hrvatskom kontekstu. Primjerice, Dujmović (2007) je ispitao stavove studenata o uporabi J1 u nastavi engleskog jezika. Rezultati pokazuju da svi ispitanici smatraju da se J1 treba upotrebljavati u nastavi, a najčešće funkcije koje spominju jesu objašnjavanje složenijih 
gramatičkih pitanja te objašnjavanje novog vokabulara. Erk (2017) je pak, između ostaloga, istraživala učestalost uporabe i stavove nastavnika koji poučavaju engleski jezik u osnovnoj školi, srednjoj školi i na fakultetskoj razini prema ulozi J1. Rezultati pokazuju da ispitanici imaju uglavnom pozitivan stav o ulozi J1 i gotovo svi nastavnici u određenoj mjeri u nastavi koju izvode koriste se J1. Učestalost uporabe povezana je s jezičnim i društveno-kulturnim značajkama konteksta u kojem se poučavanje odvija.

Budući da, prema našim saznanjima, u hrvatskom kontekstu nedostaje radova koji bi se bavili uporabom hrvatskoga kao J1 u nastavi španjolskoga jezika, našim smo istraživanjem željeli pridonijeti rasvjetljavanju tog pitanja.

\section{ISTRAŽIVANJE O UPORABI HRVATSKOGA JEZIKA NA SATU ŠPANJOLSKOGA JEZIKA}

\subsection{Cilj istraživanja}

Cilj je našeg istraživanja utvrditi učestalost i funkcije uporabe J1 u nastavi španjolskoga jezika te ispitati stavove učenika i nastavnika o tom pitanju.

\subsection{Ispitanici}

Istraživanje je provedeno u dvije zagrebačke gimnazije. Sudjelovalo je 34 učenika drugog razreda ( 28 učenica i 6 učenika) u dobi od 15 i 16 godina, koji španjolski jezik uče drugu godinu te je njihova pretpostavljena razina znanja A1/A2 prema Zajedničkom europskom referentnom okviru za jezike (Vijeće Europe, 2005). Sudjelovale su i dvije nastavnice, od kojih jedna ima 7, a druga 20 godina nastavnog iskustva.

\subsection{Metodologija i postupak}

Istraživanje je provedeno kvalitativnom i kvantitativnom metodom, a uključilo je promatranje nastavnih sati, anketiranje učenika i intervjuiranje nastavnica.

Za prikupljanje podataka na nastavnim satima koristili smo se tablicom za promatranje prema Galindo Merino (2012). Tablica omogućuje bilježenje općih informacija o promatranom satu (razred, nastavnik, razina, datum i sat promatranja) te sadrži odjeljak za unos funkcija uporabe J1 i odjeljak za bilježenje učestalosti uporabe, odnosno iskaza nastavnika/učenika na satu. Odjeljci su podijeljeni s obzirom na jezik (španjolski i hrvatski) i na osobu koja u određenom trenutku govori (učenik i nastavnik). Nastavu su istovremeno promatrala dva istraživača, pri čemu se jedan usredotočio na bilježenje funkcija uporabe J1, a drugi iskaza nastavnika i učenika. Promatranje ponašanja u didaktičkom okruženju obuhvatilo je ukupno 180 minuta nastave. Sadržaji nastave bili su raznoliki, što nam je omogućilo 
uvid u različite didaktičke situacije, a posljedično i upotrijebljene funkcije uporabe J1.

Stavove učenika ispitali smo upitnikom sastavljenim na temelju instrumenata korištenih u istraživanjima koja su proveli Schweers (1999) i Galindo Merino (2012). Upitnik je sastavljen na hrvatskome jeziku, a uključuje pitanje o procjeni važnosti uporabe J1 u nastavi za proces ovladavanja španjolskim jezikom i skalu od 17 čestica koje se odnose na stavove o funkcijama uporabe J1 u nastavi $(\alpha=.835)$ koju su učenici procjenjivali Likertovom ljestvicom od pet stupnjeva (u rasponu od $1-\mathrm{u}$ potpunosti se ne slažem do $5-\mathrm{u}$ potpunosti se slažem). Također su ponuđena i četiri otvorena pitanja koja se odnose na slobodnu procjenu stvarne i poželjne uporabe J1 u nastavi španjolskoga jezika u koju su uključeni. Sudjelovanje u anketiranju bilo je anonimno.

Predložak za polustrukturirani intervju s nastavnicama također je sastavljen na temelju instrumenata korištenih $u$ istraživanjima koja su proveli Schweers (1999) i Galindo Merino (2012), a sastoji se od pitanja otvorenog i zatvorenog tipa pomoću kojih smo prikupili podatke o njihovu stavu o ulozi J1 u procesu ovladavanja inim jezikom u formalnoj sredini, o iskustvu tijekom poučavanja (učestalost uporabe, funkcija uporabe, čimbenici koji na to utječu) te o procjeni stvarne i poželjne uporabe hrvatskoga jezika u nastavi španjolskoga jezika.

Prvo smo promatrali nastavne sate, zatim su učenici ispunili upitnik i na kraju je proveden intervju s nastavnicama.

\subsection{Rezultati}

U ovom odjeljku prikazat ćemo podatke o učestalosti uporabe J1 na satu španjolskoga jezika, funkcijama te uporabe kao i o stavovima ispitanika o uporabi J1 u didaktičkom okruženju.

\subsubsection{Uporaba materinskoga jezika na satu španjolskoga jezika}

Na globalnoj razini na promatranim se satima u 57 \% iskaza upotrebljavao hrvatski jezik, a u 43 \% španjolski. Drugim riječima, učenici i nastavnice nešto više od polovice vremena komunicirali su na J1.

U tablici 1 prikazani su podaci o zabilježenim funkcijama uporabe J1 na satovima španjolskog jezika kao i o udjelu španjolskoga i hrvatskoga jezika u govoru nastavnika i učenika. 
JELIĆ, Vlašić: UPORABA MATERINSKOGA JEZIKA U RAZREDNOM DISKURSU... (STR. 227-245)

Tablica 1. Funkcije uporabe J1 te udio hrvatskoga i španjolskoga jezika u govoru nastavnika i učenika na satu

\begin{tabular}{|l|c|c|c|c|c|}
\hline \multirow{2}{*}{ Funkcije uporabe J1 } & \multicolumn{2}{|c|}{ Nastavnik } & \multicolumn{2}{c|}{ Učenik } & Prosječno \\
\cline { 2 - 6 } & hrvatski & španjolski & hrvatski & španjolski & hrvatski \\
\hline Temeljne funkcije & $100 \%$ & $/$ & $93,8 \%$ & $6,2 \%$ & $96,9 \%$ \\
\hline Uklanjanje nejasnoća & $91,3 \%$ & $8,7 \%$ & $/$ & $/$ & $91,3 \%$ \\
\hline Usporedba (J1/SJ) & $85,7 \%$ & $14,3 \%$ & $85,7 \%$ & $14,3 \%$ & $85,7 \%$ \\
\hline Objašnjavanje gramatičkoga sadržaja & $76,9 \%$ & $23,1 \%$ & $/$ & $/$ & $76,9 \%$ \\
\hline Objašnjavanje leksičkoga sadržaja & $64,7 \%$ & $35,3 \%$ & $85,7 \%$ & $14,3 \%$ & $75,2 \%$ \\
\hline Provjera razumijevanja & $64,3 \%$ & $35,7 \%$ & $/$ & $/$ & $64,3 \%$ \\
\hline Poticaj (J1>SJ) & $52,7 \%$ & $47,3 \%$ & $/$ & $/$ & $52,7 \%$ \\
\hline $\begin{array}{l}\text { Objašnjavanje sociokulturnoga } \\
\text { sadržaja }\end{array}$ & $40 \%$ & $60 \%$ & $/$ & $/$ & $40 \%$ \\
\hline Ispravljanje & $38,7 \%$ & $61,3 \%$ & $/$ & $/$ & $38,7 \%$ \\
\hline Davanje povratne informacije & $25,6 \%$ & $74,4 \%$ & $0 \%$ & $100 \%$ & $25,6 \%$ \\
\hline Ponavljanje & \multicolumn{7}{|l|}{$51,1 \%$} & $8,8 \%$ & $/$ & $/$ & $91,1 \%$ \\
\hline Društvene funkcije & $80,1 \%$ & $19,9 \%$ & $/$ & $/$ & $80,1 \%$ \\
\hline $\begin{array}{l}\text { Organizacija rada i održavanje } \\
\text { discipline }\end{array}$ & $50 \%$ & $50 \%$ & $50 \%$ & $50 \%$ & $50 \%$ \\
\hline Davanje uputa & & & & \\
\hline Pozdravljanje & & & & \\
\hline
\end{tabular}

Kao što možemo vidjeti, tijekom promatranih nastavnih sati uočili smo raznolike funkcije uporabe J1, i one temeljne i one društvene. Među temeljnim funkcijama najzastupljenije su bile uklanjanje nejasnoća $(96,9 \%)$, usporedba J1 i SJ $(91,3 \%)$, objašnjavanje gramatičkoga $(85,7 \%)$ i leksičkoga sadržaja $(76,9 \%)$ te provjera razumijevanja $(75,2 \%)$. Među društvenim funkcijama najčešće je bila zastupljena funkcija organizacije rada i održavanja discipline $(91,1 \%)$ te ona koja se odnosi na davanje uputa $(80,1 \%)$.

$\mathrm{U}$ nastavku se navedenim kvantitativnim podacima pridružuju i kvalitativni podaci u smislu osvrta i isječaka iz prijepisa razrednoga diskursa i daje pregled po svakoj pojedinoj funkciji.

1. Uklanjanje nejasnoća.

Za uklanjanje nejasnoća gotovo se isključivo $(96,9 \%)$ upotrebljava materinski jezik.

(1) N: Ahora decidme qué piensa Stefan, ¿cómo se aprende una lengua extranjera?

U: Što? Što mi mislimo o njegovom mišljenju? 
$\mathrm{N}$ : Ne, trebate mi reći što Stefan misli; što je potrebno raditi kako bi naučio jezik.

Učenik postavlja pitanje nastavnici nakon što je postavila pitanje, odnosno prije obavljanja zadatka. S obzirom na to da vjerojatno nedovoljno vlada stranim jezikom, obraća se nastavnici na materinskom jeziku. To pokazuje da se učenici osjećaju slobodnima tražiti pomoć od nastavnika na J1, a u želji da razumiju zadatak i kasnije ga mogu i ispuniti. Objašnjenje koje slijedi odvija se na J1 jer neki učenici očito nisu razumjeli upute na španjolskom jeziku.

2. Usporedba (J1/SJ).

U većini iskaza (91,3\%) usporedba između gramatičkih struktura stranog i materinskog jezika odvija se na J1.

(2) N: Povratni glagoli funkcioniraju kao u hrvatskom: tuširam se, oblačim se, samo što je u španjolskom povratna zamjenica ispred glagola: me ducho, me visto.

Nastavnica izravno uspoređuje J1 i strani jezik kako bi učenicima olakšala uporabu povratnih glagola u španjolskom. Budući da se u vezi s tim gramatičkim elementom u međujeziku hrvatskih učenika španjolskog jezika može pojaviti negativni transfer iz materinskog jezika, nastavnica želi biti sigurna da su svi učenici razumjeli objašnjenje te se stoga koristi J1.

3. Objašnjavanje gramatičkoga sadržaja.

Čini se da je uobičajeno da se o gramatičkim sadržajima razgovara na J1 pa je zastupljenost materinskoga jezika kod ove funkcije vrlo visoka $(85,7 \%)$. Ipak, bilo bi optimalno da gramatičko objašnjenje dolazi nakon komunikacije na stranome jeziku tijekom koje se gramatičkim sadržajima pristupalo induktivno. Budući da se tijekom promatranih sati nije obrađivao novi sadržaj, raspolažemo s primjerima objašnjenja pomoću kojih se pokušalo osvježiti i utvrditi znanje.

$\mathrm{N}$ : Ovaj oblik estar + gerund je kao u engleskom I am studying, I am having fun.

Nastavnica se u komunikaciji o gramatičkom sadržaju koristi J1. Također je zanimljivo da se osim hrvatskim jezikom nastavnica poslužila i engleskim jezikom koji je kao strani jezik zajednički i najčešće blizak svim učenicima pa može biti vrijedna pomoć u razumijevanju gramatičkih elemenata španjolskoga jezika.

4. Objašnjavanje leksičkoga sadržaja.

U 76,9\% iskaza nepoznate se riječi jednostavno prevode na hrvatski, a rjeđe $(23,1 \%)$ se daje objašnjenje na stranome jeziku ili se čak povezuje s leksičkim jedinicama iz drugih jezika. 
(4) U: Što znači soler?

$\mathrm{N}$ : To je glagol običavati.

Nastavnica je odlučila prevesti nepoznatu riječ koju učenik nije razumio te nije ponudila ni parafrazu ni eventualni kontekst uporabe na temelju kojeg bi učenik mogao pretpostaviti značenje te riječi.

5. Provjera razumijevanja.

Razumijevanje se obično provjerava nakon čitanja ili slušanja novog teksta, davanja uputa ili kada učenik nešto ne razumije. Ono se najčešće $(75,2 \%)$ odvija na materinskom jeziku.

(5) N: Jeste li svi razumjeli što treba?

U: Da.

N: Da čujem. Karmen?

U1: Trebamo jedan drugoga pitati po ovim natuknicama i onda, kad nas prozovete, prepričati.

N: Tako je.

Kako bi provjerila razumijevanje uputa, nastavnica se koristi J1.

6. Poticaj (J1>SJ).

Učenike se na korištenje španjolskoga jezika češće potiče na J1 (64,3\%) nego na stranom jeziku.

(6) N: ¿Te gusta viajar?

U: Onako.

$\mathrm{N}$ : Na španjolski, molim te. Možeš reći más o menos.

Nastavnica zahtijeva da se komunikacija odvija na španjolskom, nudeći učenicima ekvivalent na stranome jeziku ako ne znaju izreći ono što imaju na umu.

7. Objašnjavanje sociokulturnoga sadržaja.

Nastavnice se odlučuju i za J1 i za strani jezik kada objašnjavaju razlike između hrvatskoga i hispanofonoga svijeta. Ponekad nastavniku može biti teško učenicima približiti stranu kulturu, a i moguće je da neće svi učenici razumjeti sadržaj zbog nepoznatih riječi. Zbog toga se u 52,7 \% iskaza komunikacija odvija na J1.

(7) N: Španjolci kažu Nochevieja; mi kažemo „Stara godina“. A medianoche jedu 12 zrna grožđa za sreću.

Nastavnica uspoređuje nazive kulturoloških elemenata na španjolskom i hrvatskom jeziku kako bi učenicima bilo razumljivije o čemu je riječ. U drugoj se rečenici ponovno koristi prebacivanjem koda: započinje ju na 
španjolskom jeziku, vjerojatno jer učenici već poznaju izraz, i završava na J1 kako bi bila sigurna da su svi razumjeli sadržaj koji je željela prenijeti.

8. Ispravljanje.

Nastavnice reagiraju odmah nakon što uoče pogrešku i ispravljaju je nešto češće na španjolskom nego na hrvatskom jeziku (40\%).

$\mathrm{U}$ : Ella vivo con sus padres.

$\mathrm{N}$ : ¿Ella vivo? Konjugiraj mi glagol vivir.

Nastavnica ponavlja dio rečenice koji nije točan na španjolskom jeziku upitnom intonacijom kojom ukazuje na pogrešku, a zatim daje upute na J1 kako bi učenik samostalno došao do rješenja na španjolskom. Mogli bismo to nazvati i vrstom metalingvističkog objašnjenja koje se često odvija na J1.

9. Davanje povratne informacije.

Nastavnice obično daju povratnu informaciju za većinu učenikovih odgovora. Najčešće se koriste španjolskim jezikom, a J1 pojavljuje se u otprilike trećini situacija $(38,7 \%)$.

(9) N: Super si to formulirala.

Podrobnija pohvala na materinskom jeziku možda učeniku predstavlja veći poticaj za daljnji rad nego uobičajena kratka pohvala na španjolskom jeziku (najčešće ustaljeno - muy bien).

10. Ponavljanje.

Ova funkcija vrlo je česta u nastavi stranoga jezika jer prisjećanje prethodno stečenog znanja uvijek predstavlja dobru osnovu za ovladavanje novim sadržajem. To je ujedno i osnovna funkcija u kojoj je materinski jezik najmanje zastupljen (25,6 \%), odnosno ponavljanje se uspješno odvija na španjolskom jeziku pomoću pitanja koja postavlja nastavnik, a koja pomažu učenicima ponoviti gramatičke i leksičke sadržaje.

(10) N: ¿Qué está haciendo Ana? To smo prošli put radili. ¿Cómo se dice „brisati“? ¿Cómo se dice „čistiti“?

$\mathrm{U} 1$ : Limpiar.

$\mathrm{N}$ : Entonces, ¿qué está haciendo Ana?

U2: Está limpiando la pizarra.

$\mathrm{N}$ : ¿De qué hablamos la vez pasada?

U3: Hablamos de una fiesta.

$\mathrm{N}$ : ¿Qué está haciendo la gente en la foto?

U2: Está bailando, charlando...

Nastavnica podsjeća na sadržaj koji se obrađivao prošli sat i u istom iskazu koristi se prebacivanjem koda da učenike potakne na uporabu odgovarajuće 
leksičke jedinice i na komunikaciju na stranom jeziku. Učenici dobro reagiraju i ostatak komunikacije vrlo se uspješno odvija na španjolskom jeziku.

Međutim, bilo je i iskaza u kojima je kod ponavljanja J1 bio značajno zastupljen.

(11) N: Više baš nemamo vremena. Još četiri minute. Imate li kakvih pitanja? Ajmo ponoviti prezent; vidim da s tim imate problema. Glagol cantar.

U: Canto, cantas, canta, cantamos, cantáis, cantan.

Suočena s nedostatkom vremena, nastavnica se koristi J1 kako bi ubrzala komunikaciju i bila sigurna da ju svi razumiju, ali i da se učinkovito obavi vježba ponavljanja. Takve primjere uporabe materinskoga jezika uočili smo na svim promatranim satima.

11. Organizacija rada i održavanje discipline.

Organizacijska i disciplinska pitanja nastavnice najčešće $(91,1$ \%) rješavaju na materinskom jeziku jer je to, čini se, mnogo učinkovitije.

(12) N: Vi koji mi niste donijeli sastavke, donesite drugi put. Jedinice ću dijeliti.

Nastavnica je navedeno upozorenje dala na samom početku sata pa se stječe dojam da su početak i završetak nastavnoga sata najmanje poticajne faze za uporabu stranoga jezika.

(13) N: Cure, molim vas. ¿Podemos?

Nakon što upozori učenice na J1, nastavnica se koristi španjolskim jezikom kako bi se nastavilo s radom.

12. Davanje uputa.

Ova funkcija vrlo je važna u nastavi s obzirom na to da učenici moraju razumjeti upute kako bi mogli uspješno obaviti vježbe ili napisati domaću zadaću. Zbog toga je često potrebno dati upute na hrvatskom jeziku (80,1 \% iskaza) ili kombinirati uporabu J1 i SJ.

(14) N: Mirad estos dibujos y también mirad el texto a la derecha. Vamos a adaptar este texto a Zagreb. Svi razmišljajte što biste mogli reći za Zagreb.

Uputa koju je nastavnik dao na stranome jeziku djelomično se parafrazira i nadopunjava na J1 kako bi nastavnica bila sigurna da svi razumiju i mogu krenuti na obavljanje zadatka.

(15) N: Za domaću zadaću imate na 97. stranici zadatak broj dva, ovih pet rečenica. 
Upute za domaću zadaću daju se na hrvatskom, i to bez iznimke. Upute se daju na kraju sata kad je atmosfera opuštenija i manje formalna jer već vlada užurbanost izazvana školskim zvonom (ili očekivanjem školskog zvona). To je, čini se, za nastavnice najsigurniji način za davanje uputa, kako bi se izbjegli nesporazumi, posebice jer brojevi stranica ili vježbi često predstavljaju problem učenicima.

13. Pozdravljanje.

Kod ove funkcije hrvatski i španjolski jezik jednako su zastupljeni i kod učenika i kod nastavnica (50 \%). Imajući na umu da je riječ o satu stranoga jezika, očekivalo bi se da se nastavnik i učenik pozdravljaju na stranome jeziku. Riječ je o stalnim jezičnim oblicima kojima se brzo ovladava i predstavljaju osnovni element pripreme učenika za buduću komunikaciju u prirodnoj sredini. Kada je jezična uporaba poznata i može se predvidjeti, kao što je slučaj s pozdravljanjem na početku i na kraju sata, ciljni jezik lakše je upotrebljavati (Turnbull i Dailey O'Cain, 2009). Uvijek kada nastavnica prva pozdravlja, taj dio sata odvija se na španjolskom, ali primijetili smo da učenici koji kasne na sat na ulazu pozdravljaju na hrvatskom jeziku. Također se koriste J1 kako bi se ispričali, a tada nastavnice s njima razgovaraju na hrvatskom.

N: Vidimo se, doviđenja!

U: Doviđenja!

Za pozdravljanje na kraju sata u samo 50 \% iskaza upotrebljava se španjolski jezik. Čini se da se u tom posljednjem dijelu sata gube formalne značajke nastave zbog umora, nedostatka koncentracije ili vremena pa se komunikacija češće odvija na J1.

\subsubsection{Stavovi učenika o uporabi materinskoga jezika na satu španjolskoga jezika}

Učenici općenito smatraju da uporaba hrvatskoga jezika u nastavi pospješuje proces ovladavanja španjolskim jezikom $(\mathrm{M}=4,21$; $\mathrm{SD}=1,17)$.

U tablici 2 prikazane su srednje vrijednosti odgovora učenika na čestice koje se odnose na stavove o funkcijama uporabe hrvatskoga jezika u nastavi španjolskoga jezika. 
JELIĆ, Vlašić: UPORABA MATERINSKOGA JEZIKA U RAZREDNOM DISKURSU... (STR. 227-245)

Tablica 2. Stavovi učenika o funkcijama uporabe J1 u nastavi španjolskog jezika

\begin{tabular}{|l|c|c|c|c|}
\hline Čestica & Min & Max & M & SD \\
\hline Hrvatskim se potrebno koristiti za objašnjavanje vokabulara. & 1 & 5 & 4,59 & 0,82 \\
\hline Hrvatskim se potrebno koristiti za uklanjanje nejasnoća. & 3 & 5 & 4,52 & 0,71 \\
\hline $\begin{array}{l}\text { Hrvatskim se potrebno koristiti za davanje uputa za vježbe/ } \\
\text { aktivnosti. }\end{array}$ & 2 & 5 & 4,44 & 0,79 \\
\hline $\begin{array}{l}\text { Hrvatskim se potrebno koristiti za tumačenje gramatičkih } \\
\text { sadržaja. }\end{array}$ & 2 & 5 & 4,38 & 0,78 \\
\hline $\begin{array}{l}\text { Hrvatskim se potrebno koristiti za usporedbu hrvatskoga i } \\
\text { španjolskoga jezika. }\end{array}$ & 2 & 5 & 4,24 & 0,89 \\
\hline Hrvatskim se potrebno koristiti za uvod u sat. & 1 & 5 & 4,15 & 0,96 \\
\hline $\begin{array}{l}\text { Hrvatskim se potrebno koristiti za davanje uputa za domaću } \\
\text { zadaću. }\end{array}$ & 2 & 5 & 4,09 & 1,06 \\
\hline $\begin{array}{l}\text { Hrvatskim se potrebno koristiti za održavanje discipline u } \\
\text { razredu. }\end{array}$ & 1 & 5 & 4,00 & 1,07 \\
\hline Hrvatskim se potrebno koristiti za izvanjezični sadržaj. & 1 & 5 & 3,85 & 1,35 \\
\hline Hrvatskim se potrebno koristiti za sociokulturni sadržaj. & 1 & 5 & 3,76 & 1,02 \\
\hline $\begin{array}{l}\text { Hrvatskim se potrebno koristiti za provjeru učenikova } \\
\text { razumijevanja. }\end{array}$ & 1 & 5 & 3,71 & 1,24 \\
\hline $\begin{array}{l}\text { Hrvatskim se potrebno koristiti za vrednovanje učenikova } \\
\text { odgovora. }\end{array}$ & 1 & 5 & 3,53 & 1,19 \\
\hline Hrvatskim se potrebno koristiti u izvođenju vježbi/aktivnosti. & 1 & 5 & 3,50 & 1,11 \\
\hline $\begin{array}{l}\text { Hrvatskim se potrebno koristiti za ispravljanje učenikova } \\
\text { odgovora. }\end{array}$ & 1 & 5 & 3,35 & 1,25 \\
\hline $\begin{array}{l}\text { Hrvatskim se potrebno koristiti za ponavljanje sadržaja s } \\
\text { prethodnog sata. }\end{array}$ & 1 & 5 & 3,32 & 1,15 \\
\hline Hrvatskim se potrebno koristiti za ponavljanje stečenog znanja. & 1 & 5 & 3,24 & 1,30 \\
\hline Hrvatskim se potrebno koristiti za pozdravljanje. & 5 & 2,06 & 1,37 \\
\hline
\end{tabular}

Učenici smatraju da materinski jezik u prvom redu treba upotrebljavati za objašnjavanje jezičnih sadržaja, tj. vokabulara $(\mathrm{M}=4,59 ; \mathrm{SD}=0,82) \mathrm{i}$ gramatike $(\mathrm{M}=4,38 ; \mathrm{SD}=0,78)$, uklanjanje nejasnoća $(\mathrm{M}=4,52 ; \mathrm{SD}=0,71)$, usporedbu J1 i stranoga jezika $(\mathrm{M}=4,24 ; \mathrm{SD}=0,89)$ te $\mathrm{u}$ organizacijske svrhe poput davanja uputa za vježbe i aktivnosti $(\mathrm{M}=4,44$; $\mathrm{SD}=0,79)$ ili domaće zadaće $(\mathrm{M}=4,09 ; \mathrm{SD}=1,06)$, uvoda u sat $(\mathrm{M}=4,15 ; \mathrm{SD}=0,96)$ i održavanje discipline $(\mathrm{M}=4,00 ; \mathrm{SD}=1,07)$. Nešto manja zastupljenost trebala bi biti kod komunikacije o izvanjezičnom sadržaju $(\mathrm{M}=3,85 ; \mathrm{SD}=1,35)$, sociokulturnom sadržaju $(\mathrm{M}=3,76 ; \mathrm{SD}=1,02)$ te pri provjeri učenikova razumijevanja $(\mathrm{M}=$ $3,71 ; \mathrm{SD}=1,24)$ i izvođenju vježbi $(\mathrm{M}=3,50 ; \mathrm{SD}=1,11)$. Vrednovanje $(\mathrm{M}=3,53$; $\mathrm{SD}=1,19)$ i ispravljanje pogrešaka $(\mathrm{M}=3,35 ; \mathrm{SD}=1,25)$ samo bi se djelomično trebali odvijati na J1 kao i ponavljanje općenito (i sadržaja s prethodnog sata $\mathrm{M}=3,32 ; \mathrm{SD}=1,15$ i stečenog znanja $(\mathrm{M}=3,24 ; \mathrm{SD}=1,30))$. Kod funkcije pozdravljanja procjenjuju da bi uporaba J1 trebala biti najmanje zastupljena $(\mathrm{M}=2,06 ; \mathrm{SD}=1,37)$. 
Učenici su također u obliku postotka trebali procijeniti koliko oni sami upotrebljavaju materinski jezik na satu španjolskoga jezika i koliko često to čine njihove nastavnice. Također ih se potaknulo da izraze svoj stav (u obliku postotka) o tome u kojoj bi mjeri oni sami trebali upotrebljavati materinski jezik u komunikaciji na satu stranoga jezika kako bi što bolje napredovali u procesu ovladavanja, a u kojoj bi mjeri to trebale činiti njihove nastavnice. Usporedni rezultati prikazani su na slici 1.

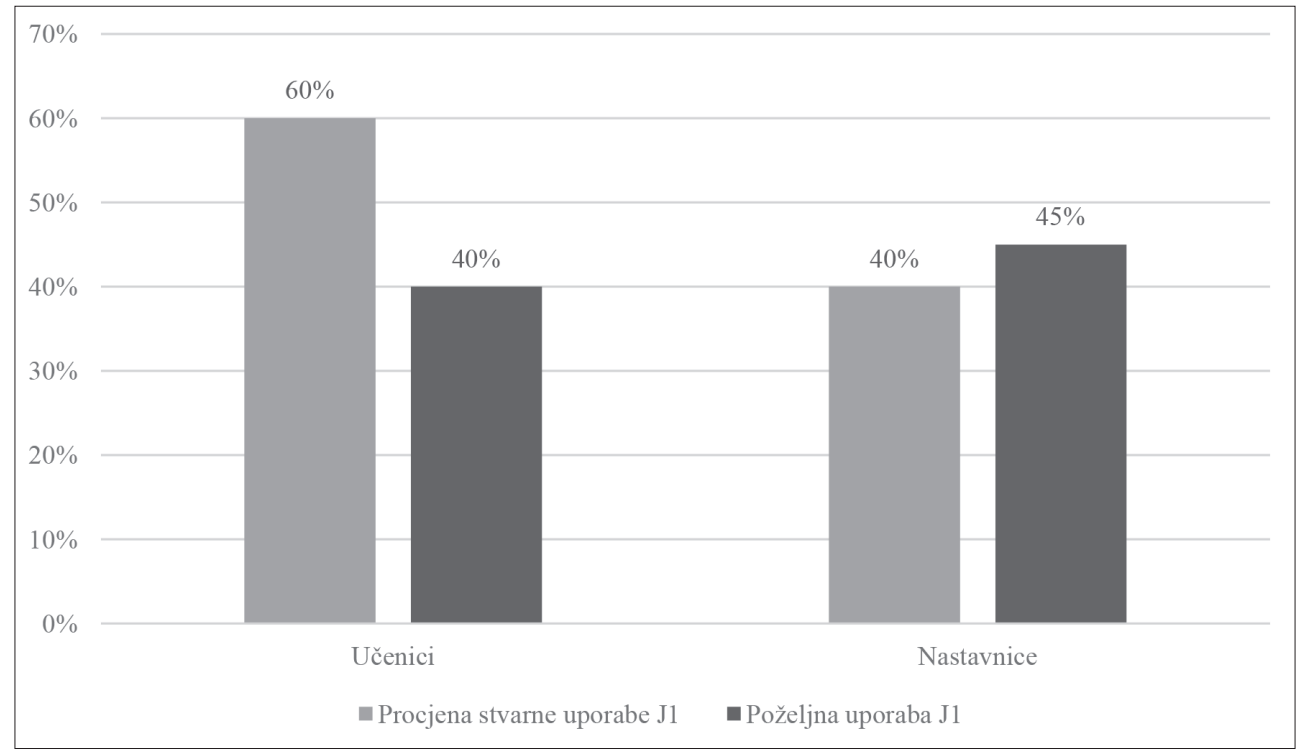

Slika 1: Procjena učenika o stvarnoj i poželjnoj uporabi J1 na satu španjolskoga jezika

Učenici procjenjuju da se oni sami koriste materinskim jezikom $\mathrm{u}$ otprilike $60 \%$ komunikacije na satu španjolskoga jezika te da se nastavnice hrvatskim jezikom koriste oko $40 \%$ vremena. Također smatraju da bi oni trebali manje upotrebljavati materinski jezik (40\%), ali da bi ga nastavnice trebale upotrebljavati nešto češće nego što učenici smatraju da one to čine (45 \%). Treba dodati da nitko od učenika ne želi da se nastava odvija isključivo na španjolskome jeziku; najmanji željeni postotak za uporabu hrvatskoga jezika iznosio je $20 \%$.

\subsubsection{Stavovi nastavnica o uporabi materinskoga jezika na satu španjolskoga jezika}

Nastavnice smatraju da materinski jezik ima važnu ulogu u procesu ovladavanja španjolskim jezikom, ali da o kontekstu poučavanja ovisi u kojoj bi mjeri on trebao biti zastupljen. Svjesne su činjenice da su one učenicima važan izvor razumljivog unosa (Krashen, 1982, 1985) te da što se češće komunikacija odvija na španjolskome jeziku, to će učenici imati prilike bolje ga usvojiti. Nastavnice nemaju neka unaprijed određena osobna pravila o 
tome u kojim situacijama upotrebljavaju J1. Jedna od nastavnica smatra da se hrvatskim jezikom koristi podjednako na svim razinama poučavanja, dok druga navodi da se materinskim jezikom sve rjeđe koristi kako je razina znanja njezinih učenika viša. Jedna priznaje da se u određenoj mjeri osjeća krivom dok se koristi materinskim jezikom na satu, dok druga to ne smatra nedostatkom.

Njihovi odgovori ne razlikuju se mnogo s obzirom na stav o tome koja je funkcija uporabe J1: vjeruju da se J1 treba koristiti za uklanjanje nejasnoća, ponavljanje, obradu sociokulturnog sadržaja, usporedbu J1/SJ i organizaciju rada. Jednoj nastavnici čini se korisnim upotrebljavati španjolski jezik za uvod, a materinski za ponavljanje i za davanje uputa, i to iz praktičnih razloga. Za razliku od nje, druga nastavnica objašnjava da sve to u velikoj mjeri ovisi o situaciji i o okolnostima. Obje se slažu da će upravo situacija i okolnosti nastavnog procesa utjecati na to hoće li se za objašnjavanje leksičkoga sadržaja, održavanje discipline, vrednovanje i ispravljanje kao i za provjeru razumijevanja koristiti materinskim ili španjolskim jezikom. Jedna nastavnica smatra da je bolje objašnjavati gramatiku na materinskome jeziku, dok se druga odlučuje za kombinaciju jednog i drugog jezika.

Kao i učenici, i nastavnice su u obliku postotka trebale procijeniti koliko one same upotrebljavaju materinski jezik na satu španjolskoga jezika i koliko često to čine njihovi učenici. Također ih se potaknulo da izraze svoj stav (u obliku postotka) o tome u kojoj bi mjeri one same trebale upotrebljavati materinski jezik na satu stranoga jezika kako bi omogućile učenicima da što bolje napreduju u procesu ovladavanja, a u kojoj bi mjeri to trebali činiti njihovi učenici. Nastavnice smatraju da na satu španjolskoga jezika upotrebljavaju materinski jezik prosječno $35 \%$ vremena te da bi tu uporabu trebalo smanjiti na $25 \%$ vremena. Procjenjuju da učenici upotrebljavaju materinski jezik 70 $\%$ vremena, a da bi bilo poželjno tu uporabu smanjiti na $35 \%$.

\subsubsection{Rasprava}

Cilj ovoga rada bio je istražiti učestalost i funkcije uporabe hrvatskoga jezika u nastavi španjolskoga jezika te ispitati stavove učenika i nastavnika o tom pitanju.

Obje skupine ispitanika iz našeg istraživanja smatraju da hrvatski jezik ima pozitivnu ulogu u procesu ovladavanja španjolskim jezikom i smatraju da treba biti zastupljen $\mathrm{u}$ formalnom okruženju poučavanja, ali pod određenim uvjetima. Podaci se podudaraju s nalazima prethodnih istraživanja (Carlson, 2010; Dujmović, 2007; Erk, 2017; Galali i Cinkara, 2017; Schweers, 1999), bez obzira na individualne razlike ispitanika, njihove različite razine znanja i različite značajke okruženja u kojem su ona provedena.

Promatranjem nastavnih sati utvrdili smo da učenici i nastavnice nešto više od polovice vremena komuniciraju na J1, što se podudara s procjenama 
Littelwood i Yu (2011) kao i rezultatima iz istraživanja Galindo Merino (2012), iako su općenito u literaturi nalazi vezani za to pitanje vrlo heterogeni i rasponi vrijednosti značajni (Erk, 2017). Učenici su samoprocjenom otprilike potvrdili te podatke. Zanimljivo je i da im se čini kako nastavnice nešto manje upotrebljavaju J1 nego što je to zaista slučaj, odnosno smatraju da su više izloženi španjolskome jeziku nego što doista jesu, vjerojatno zato što na svojoj razini znanja moraju uložiti znatni napor za razumijevanje nastavnikova govora. S druge strane, nastavnice su procijenile da mnogo manje upotrebljavaju hrvatski jezik nego što je to uistinu slučaj. To ukazuje na određeni manjak svjesnosti nastavnica o udjelu vremena tijekom kojeg se koriste J1. Nažalost, povećanom uporabom materinskoga jezika učenicima na određeni način uskraćuju izloženost razumljivom unosu koji im je $\mathrm{u}$ velikoj mjeri potreban kako bi uspješno ovladavali stranim jezikom, čak i kad je riječ o početnim razinama znanja, kao što je ovdje slučaj. Treba, naime, imati na umu da je nastavnik vrlo važan izvor razumljivog unosa, posebno u nastavi onih jezika kojima učenici nisu u velikoj mjeri izloženi izvan didaktičke sredine.

Analizirajući funkcije možemo reći da je, zbog donekle podređenog položaja učenika u didaktičkom okruženju (Čurković Kalebić, 2002, 2008), ukupni broj funkcija u kojem sudjeluju učenici znatno manji od broja funkcija kojima se koriste nastavnice. Pritom se nastavnice češće koriste materinskim jezikom od učenika. Naši podaci potvrđuju dihotomiju funkcija koju spominje Kerr (2019). Hrvatski se jezik u na satu španjolskoga jezika koristi s jedne strane $\mathrm{u}$ funkciji poučavanja, tj. potpore procesu ovladavanja tim jezikom i to u prvom redu za uklanjanje nejasnoća i usporedbu J1 i J2, i tek nešto rjeđe za objašnjavanje gramatičkoga i leksičkoga sadržaja te za provjeru razumijevanja, a s druge, u svojoj društvenoj funkciji pa ga nastavnice rabe za organizaciju rada, održavanje discipline, davanje uputa i, iznenađujuće, pozdravljanje. Rezultati našeg istraživanja i u tom smislu potvrđuju nalaze prethodnih istraživanja (Dujmović, 2007; Galindo Merino 2012; Schweers, 1999) kad govorimo o funkcijama J1 u nastavi vezanim za objašnjavanje leksičkoga sadržaja i davanja uputa. Međutim, u našem su slučaju, osim navedenih, najzastupljenije funkcije koje uključuju uklanjanje nejasnoća, usporedbu J1 i SJ i davanje uputa i one se gotovo isključivo odvijaju na hrvatskome jeziku. U nešto manjoj su mjeri, iako i dalje značajno, zastupljene funkcije objašnjavanja gramatičkoga sadržaja i davanja uputa. Iako Galindo Merino (2012) spominje da je ispravljanje često zastupljena funkcija J1, u našem je istraživanju ona bila prisutna tek u 40 \% iskaza kao i davanje povratne informacije. Takvu zastupljenost funkcija možemo povezati s kontekstom u kojem se ovladavanje španjolskim jezikom odvija - riječ je o adolescentima na početnoj razini učenja jezika u školskom okruženju te pretpostavljamo da su upravo dob ispitanika, njihova razina 
znanja španjolskoga jezika kao i formalno školsko okruženje u kojem se nalaze u bitnome odredili zastupljenost i funkcije uporabe J1.

Učenici i nastavnice uglavnom se slažu oko funkcija u kojima je zastupljenost materinskoga jezika najpoželjnija, a to su u prvom redu uklanjanje nejasnoća, usporedba J1 i SJ te organizacija rada (i održavanje discipline) i davanje uputa. Nešto manji stupanj slaganja odnosi se na jezik koji bi trebalo upotrebljavati za objašnjavanje gramatičkih i leksičkih sadržaja pri čemu učenici (kao i, primjerice, kod Dujmović, 2007) naglašavaju važnu ulogu materinskoga jezika, dok nastavnice upozoravaju na važnost konteksta poučavanja koji u velikoj mjeri može odrediti odabir jezika. Mišljenja im se također razlikuju kad govoreojeziku koji treba odabrati za ponavljanje sadržaja budući da učenici ne smatraju nužnim da se ono odvija na materinskom jeziku, dok je nastavnicama to važno. Stavovi učenika i nastavnica uglavnom se podudaraju s nastavnom praksom, ali ima i ponekih iznimaka. Iako se nastavnice zalažu za uporabu J1 u situacijama ponavljanja, na promatranim satima mnogo su češće upotrebljavale španjolski nego hrvatski jezik.

Podaci o procjenama stvarne i poželjne razine uporabe J1 na satu španjolskoga jezika ukazuju da jedni i drugi relativno dobro procjenjuju njegovu stvarnu zastupljenost. Jedni i drugi izražavaju opću potrebu za određenim smanjenjem učestalosti njegove uporabe, osim što učenici smatraju da bi nastavnice neznatno češće trebale upotrebljavati materinski jezik u nastavi što možemo objasniti činjenicom da je riječ o nastavi na početnim razinama znanja gdje je vladanje stranim jezičnim kodom na razini jezičnog razumijevanja, naravno, relativno ograničeno.

$\mathrm{Na}$ kraju, na temelju dobivenih podataka možemo spomenuti savjet za nastavnu praksu u ovom kontekstu poučavanja. Smatramo da bi trebalo razmotriti smanjenje uporabe materinskoga jezika $u$ odnosu na funkciju pozdravljanja koja bi se svakako trebala odvijati isključivo na španjolskome jeziku, ali u određenoj mjeri i na funkciju organizacije rada u smislu održavanja discipline. Naime, tu je riječ je o ritualiziranom govoru koji u određenoj mjeri sadrži stalne formule koje bi učenici trebali usvojiti tijekom nastavnih aktivnosti. Možemo pretpostaviti da će do promjena doći kako učenici budu napredovali u procesu ovladavanja španjolskim jezikom.

\section{ZAKLJUČAK}

Uporaba J1 u nastavi stranih jezika tema je o kojoj u stručnoj javnosti često postoje podijeljena mišljenja. U našem smo se radu bavili ulogom hrvatskoga kao materinskoga jezika u formalnom kontekstu ovladavanja španjolskim jezikom na primjeru ispitanika adolescentske dobi na početnoj razini učenja i njihovih nastavnica. Naši ispitanici prepoznaju pozitivnu ulogu J1 u procesu ovladavanja stranim jezikom, a učestalost i zastupljenost pojedinih uočenih funkcija kao i stavovi ispitanika o tom pitanju uvjetovani su značajkama 
specifičnog konteksta u kojem se taj proces odvija. Dobiveni podaci svakako mogu biti korisni za povećanje razine svjesnosti nastavnika španjolskoga jezika o ovoj temi, i tijekom inicijalnog i cjeloživotnog obrazovanja. U tom je smislu opravdano i zagovaranje uporabe materinskoga jezika u nastavi španjolskoga jezika radi učinkovitijeg poučavanja i s ciljem unaprjeđenja procesa ovladavanja tim jezikom u određenim funkcijama poput uklanjanja nejasnoća, objašnjavanja gramatičkoga i leksičkoga sadržaja ili usporedbe J1 i SJ, što je u skladu i sa suvremenim stavom da se višejezično obrazovanje s ciljem razvoja višejezičnosti treba temeljiti na znanjima i vještinama iz prvoga jezika (van Ginkel, 2017 u Erk, 2018).

Ograničenja našeg istraživanja u prvom redu odnose se na prigodni uzorak, broj ispitanika i na prigodni korpus promatranih nastavnih sati. Buduća istraživanja o ulozi hrvatskoga jezika u nastavi španjolskoga jezika svakako bi trebala uključivati daljnje prikupljanje podataka na većem uzorku, posebno uzimajući u obzir razinu znanja učenika, individualne čimbenike učenika i nastavnika kao i okruženje u kojem se poučavanje odvija. Dodatni instrumenti trebali bi uključivali i anketu za nastavnike i polustrukturirani intervju koji bi se organizirao s učenicima. Sve navedeno zasigurno bi omogućilo dodatno sagledavanje ovoga pitanja iz više uglova i pridonijelo boljem razumijevanju ove složene teme na temelju podataka prikupljenih $\mathrm{u}$ hrvatskom kontekstu.

\section{LITERATURA}

Brown, H. D. (2000) Principles of language learning and teaching. White Plains, NY: Pearson Education.

Carlsson, E. (2010) El rol de la lengua materna en la enseñanza en clase de lenguas extranjeras. Un estudio de caso. Tesina. Göteborg: Göteborgs Universitet. https:/gupea.ub.gu.se/bitstream/2077/23860/1/ gupea_2077_23860_1.pdf (29.9. 2014.).

Cook, V. (2001) Using the First Language in the Classroom. Canadian Modern Language Review 57 (3), 402-423.

Čurković Kalebić, S. (2002) O govoru nastavnika u nastavi stranih jezika: ponavljanje pitanja i uporaba stanki. Strani jezici 31 (3/4), 137-144.

Čurković Kalebić, S. (2003) Jezik i društvena situacija: istraživanje govora u nastavi stranog jezika. Zagreb: Školska knjiga.

Čurković Kalebić, S. (2008) Teacher talk in foreign language teaching. Split: Redak.

Dujmović, M. (2007) The use of Croatian in the EFL classroom. Metodički obzori 2 (1), 91-100.

Ellis, R. (2009) Corrective feedback and teacher development. L2 Journal 1 (1), 3-18, http://epi. sc.edu/ar/AS_4_files/Ellis,\%202009.pdf (15. 12. 2019.).

Erk, M. (2017) English language instructors' beliefs about the role of L1 in English language development and formal instruction in Croatia: A survey. Explorations in English Language and Linguistics 5 (2), 95-121.

Erk, M. (2018) Prvi jezik u teorijama ovladavanja inim jezikom i formalnom obrazovanju: od jednojezičnosti prema višejezičnosti. U Smajić, D., Krumes, I. i Mance, N. (ur.) U jezik uronjeni: zbornik posvećen Ireni Vodopiji. Osijek: Fakultet za odgojne i obrazovne znanosti u Osijeku, 269-279.

Forteza Fernández, R. (2015) The effects of L1 overuse in FL learning: Evidence from three case studies. International E-Journal of Advances in Education 1 (3), http://ijaedu.ocerintjournals.org/ tr/download/article-file/225647 (20. 12. 2019.). 
Galali, A. i Cinkara, E. (2017) The Use of L1 in English as a Foreign Language Classes: Insights from Iraqi Tertiary Level Students. Advances in Language and Literary Studies 8, 54-64.

Galindo Merino, M. M. (2011) L1 en el aula de L2: ¿Por qué no?. ELUA 25, 163-204.

Galindo Merino, M. M. (2012) La lengua materna en el aula de ELE. Málaga: ASELE.

Gass, S. (2003) Input and interaction. U Daughty, C. i Long, M. (ur.) The handbook of second language acquisition. Malden, MA: Blackwell Publishing, 224-255.

Kerr, P. (2019) The use of L1 in English language teaching. Part of the Cambridge Papers in ELT series. Cambridge: Cambridge University Press, https://languageresearch.cambridge.org/images/ CambridgePapersInELT_UseOfL1_2019_ONLINE.pdf (1.9. 2020.).

Krashen, S. (1982) Principles and Practice in Second Language Acquisition. Oxford: Pergamon.

Krashen, S. (1985) The input hypothesis: Issues and implications. New York: Longman.

Levine, G. S. (2003) Student and instructor beliefs and attitudes about target language use, first language use and anxiety: Report of a questionnaire study. The Modern Language Journal 87 (3), 343-364.

Levine, G. S. (2012) Principles for code choice in the foreign language classroom: A focus on grammaring. Language Teaching 47 (3), 332-348.

Littlewood, W. T. i Yu, B. (2011) First language and target language in the foreign language classroom. Language Teaching 44 (1), 64-77.

Macaro, E. (2005) Codeswitching in the FL Classroom: A Communication and Learning Strategy. U Llurda, E. (ur.) Non-Native Language Teachers: Perceptions, Challenges, and Contributions to the Professions. Boston: Springer, 63-84.

Macaro, E. (2009) Teacher use of codeswitching in the second language classroom. U Turnbull, M. i Dailey-O'Cain, J. (ur.) First language use in second and foreign language learning. Bristol: Multilingual Matters, 35-49.

Moghadam, S. H., Samad, A. A. i Shahraki, E. R. (2012) Code switching as a medium of instruction in an EFL classroom. Theory and Practice in Language Studies 2 (11) 2219-2225.

Nation, P. (2003) The role of the first language in foreign language learning. The Asian EFL Journal 5 (2), https://www.asian-efl-journal.com/main-journals/the-role-of-the-first-language-in-foreign-language-learning/\#thethe-tabs-1-4 (20. 12. 2019.).

Schweers, C. W. Jr. (1999) Using J1 in the SJ classroom. English Teaching Forum 37 (2), 6-9.

Thoms, J. J. (2012) Classroom discourse in foreign language classrooms: A review of the literature. Foreign Language Annals 45 (1), 8-27.

Turnbull, M. i Dailey-O'Cain, J. (ur.) (2009) First language use in second and foreign language learning. Bristol: Multilingual Matters.

Vrhovac, Y. (2001) Govorna komunikacija i interakcija na satu stranoga jezika. Zagreb: Naklada Ljevak.

Vrhovac, Y. (2003) Obilježja ,ja“ i „,ti“ u razrednom govoru. U Stolac, D., Ivanetić N. i Pritchard B. (ur.) Psiholingvistika i kognitivna znanost u Hrvatskoj primijenjenoj lingvistici, Zbornik radova HD$P L-a$. Zagreb - Rijeka: Hrvatsko društvo za primijenjenu lingvistiku, 773-784.

Vrhovac, Y. (2005) Nastavnikova i učenikova uloga u interaktivnom prostoru. U Stolac, D., Ivanetić N. i Pritchard B. (ur.) Jezik u društvenoj interakciji, Zbornik radova HDPL-a. Zagreb - Rijeka: Hrvatsko društvo za primijenjenu lingvistiku, 535-546.

Vijeće Europe (2005) Zajednički europski referentni okvir za jezike: učenje, poučavanje, ocjenjivanje - ZEROJ. Zagreb: Školska knjiga. 


\section{THE USE OF L1 IN THE SPANISH LANGUAGE CLASSROOM DISCOURSE}

The use of L1 in foreign language teaching has been a debated subject among researchers and professionals in the field for several decades. The current position regarding this issue recognises the important role played by L1 in the second language acquisition process. However, when second language acquisition takes place in an instructed setting, a number of issues related to the characteristics of L1 use arise. The aim of this paper is to determine the frequency and the functions of the use of Croatian as L1 in the Spanish foreign language classroom and to explore the beliefs of teachers and students regarding the issue. The data reveal that more than half of communication in the Spanish language classroom takes place in Croatian. L1 is used for a number of functions, among which the most prominent ones are removing ambiguities, comparison of $\mathrm{L} 1$ and $\mathrm{FL}$, managing classroom work, maintaining discipline and explaining grammar. Both students and teachers have a positive attitude towards the role of L1 in the process of instructed second language acquisition and mostly advocate its use in the Spanish language classroom in the functions in which it is present. However, it is underlined that the use of L1 is to a great extent related to the situation and the circumstances in which teaching takes place.

Keywords: L1 use, Croatian as L1, Spanish as a foreign language (ELE), communication in a foreign language classroom. 